\title{
Impact of different sterilization techniques and mass loss measurements on the durability of wood against wood-destroying fungi
}

\author{
Christian Brischke $^{1}$ (1) . Nicklas von Boch-Galhau ${ }^{1} \cdot$ Susanne Bollmus ${ }^{1}$
}

Received: 6 April 2021 / Accepted: 4 August 2021 / Published online: 14 August 2021

(c) The Author(s) 2021

\begin{abstract}
The biological durability of wood is frequently determined in laboratory tests with monocultures of different decay fungi under ideal conditions for fungal growth. To avoid contamination with mould and inhibition of fungal growth, wood specimens need to be sterilized using different methods. To determine the mass loss of wood blocks during incubation, the initial total dry mass is needed but should be determined without oven-drying to avoid the loss of volatile compounds of the tested wood. In this study the effect of different sterilization techniques in combination with different methods of determining the oven-dry weight on mass loss $\left(\mathrm{ML}_{\mathrm{F}}\right)$ in agar plate wood block tests was investigated. No significant $\mathrm{ML}_{\mathrm{F}}$ differences were observed between sterilization through gamma radiation, steam, autoclaving, ethanol dipping and oven-drying. Solely, nonsterilized specimens showed reduced $\mathrm{ML}_{\mathrm{F}}$, since the test fungus was inhibited by mould growth. Oven-drying of wood species that contain volatile and resistance-affecting compounds such as Scots pine (Pinus sylvestris) led to reduced biological durability and should either be avoided or adapted to kiln-drying temperatures usually applied in practice.
\end{abstract}

\section{Introduction}

The biological durability of wood is frequently determined in laboratory tests with monocultures of different decay fungi under ideal conditions for fungal growth (EN 113-2 2021; AWPA E 10 2015). Similar test setups can be used for determining the efficiency of wood preservatives (EN 113-1 2021; ASTM D1413-05b 2005). These experiments are rather fast, reproducible, and allow to distinguish between the effect of different decay types and even fungal species on wood degradation. To assure that (1) decay is caused by the selected test fungus exclusively, and (2) growth and decay activity of the test fungus are not inhibited by antagonistic effects caused by other organisms, it is important and requested according to different standards (e.g. EN 113-1 2021; EN 113-2 2021) that the wood test specimens are sterilized before incubation. Handling of fungal cultures and

Christian Brischke

christian.brischke@uni-goettingen.de

http://www.uni-goettingen.de/en/67096.html

1 Wood Biology and Wood Products, University of Goettingen, Buesgenweg 4, 37077 Göttingen, Germany sterilized wood specimens requires best care and attention to avoid contamination with fungal spores, mites, and bacteria.

Different sterilization techniques are available and suggested in standardized test protocols (EN 113-1 2021; EN 113-2 2021). The profile of requirements for sterilization techniques comprises the following:

- Living material inside or adhering to the wood specimens needs to get devitalized. This comprises mycelium and spores in dry state.

- The material-inherent resistance of wood against wooddegrading organisms should stay unaffected.

- No substances should be added that potentially alter the material-inherent resistance of wood.

- The sterilization technique itself should neither harm humans nor the environment.

Schmidt and French (1979) studied the effect of different sterilization methods on the germination of spores of different wood decay fungi. Small blocks of aspen (Populus termuloides) and white spruce (Picea glauca) were subjected to steaming, autoclaving, and ethylene oxide treatment, reciprocal tyndallization, as well as boiling water immersion. Two or more methods of the attempted sterilization gave erratic germination response or inhibited spore germination. 
In the past, sterilization with hot steam and gaseous pesticides (fumigants, e.g. bromine methane and monophosphane) has been common practice (Armstrong et al. 2014), but the latter was banned from laboratory practice due to health risk issues. Therefore, today steam treatments and gamma irradiation are the most common sterilization methods and recommended for instance in $\mathrm{EN}$ 113-1 (2021) and EN 113-2 (2021).

Heat sterilization is used worldwide and currently the most practical and environmentally friendly treatment to kill pests in solid wood materials (Wang 2010). Treatment schedule requirements differ between countries and depend on the type and size of objects that are traded and therefore transported. The International Standard for Phytosanitary Measures (ISPM) 'Guidelines for Regulating Wood Packaging Material in International Trade' requires heating wood to a minimum core temperature of $56{ }^{\circ} \mathrm{C}$ for a minimum of $30 \mathrm{~min}$ (IPPC 2002; APHIS 2004). For sterilizing wood specimens for biological durability tests, higher temperatures are applied such as under hot steam (EN 113-1 2021; EN 113-2 2021). Wang (2010) reviewed factors affecting the heating time needed to achieve a fully sterile substrate. Accordingly, the energy source, the type and circulation of the heating medium, the size and configuration of wood, the wood species, corresponding wood properties, and the type of stacking wood samples do significantly affect the efficacy of heat treatments.

Smith and Sharman (1971) reported on a steam sterilization at $121{ }^{\circ} \mathrm{C}$ for $30 \mathrm{~min}$ leading to fully effective sterilisation of ponderosa pine (Pinus ponderosa) and red alder (Alnus rubra) sapwood blocks without significant effect on mass loss by different decay fungi in subsequent incubation experiment. Chapman (1933) compared the effect of different steam treatments on the susceptibility of green loblolly pine (Pinus taeda) sapwood to wood-destroying fungi. He concluded that steam sterilization, especially with pressure and resultant higher temperatures, might make the wood more susceptible to fungal decay after the fungus has passed the earliest invasion stage.

Kacik et al. (2016) sterilized Scots pine (Pinus sylvestris) sapwood at $120{ }^{\circ} \mathrm{C}$ under atmospheric pressure and found an increase in the percentage of extractives and the amount of dioxane lignin yields compared to untreated wood while a decrease in the acid-insoluble lignin content was also observed. Based on FTIR studies they suggested that a cleavage of ether bonds and $\alpha$ - and $\beta$-alkyl-aryl ether bonds took place.

Gamma radiation has been shown to be effective to prevent mold growth on wood (Scheffer 1963; Hansen 1972). Freitag and Morrell (1998) showed that a ${ }^{60} \mathrm{Co}$ dosage of $15 \mathrm{kGy}$ efficiently sterilized ponderosa pine sapwood wafers. However, according to different test standards, a higher dosage is required, for example $25-50 \mathrm{kGy}$ when using a ${ }^{60} \mathrm{Co}$ source and $50-100 \mathrm{kGy}$ when a neutron accelerator is used (EN 113-1 2021; EN 113-2 2021).

Several previous studies focused on the effect of gamma irradiation on the biological durability of wood, but came to partly contradictory results and conclusions: Katsumata et al. (2007) found that the degree of polymerization of cellulose adversely decreased with increasing doses of gamma irradiation. Furthermore, termite wood consumption rates were significantly higher at $100 \mathrm{kGy}$ than at lower doses. On the other hand, the decay resistance of gamma-irradiated wood against the fungi Fomitopsis palustris and Trametes versicolor was not affected by irradiation dose in a range between 0 and $100 \mathrm{kGy}$. In contrast, Hasan et al. (2008) showed that gamma radiation significantly affected decay of Scots pine sapwood after incubation with Poria placenta. Mass loss was increased by $20 \%$ and $68 \%$ when the wood blocks were sterilized at $30 \mathrm{kGy}$ and $150 \mathrm{kGy}$ respectively, using a ${ }^{60} \mathrm{Co}$ source compared to autoclaved reference specimens.

Curling and Winandy (2008) examined the effect of gamma radiation on mass and flexural bending strength of Southern pine sapwood (Pinus spp.) in a range between 15 and $75 \mathrm{kGy}$. Bending strength decreased with increasing total dosage and dose rate $(8.5-16.9 \mathrm{kGy} / \mathrm{h})$ and it was concluded that when total gamma-irradiation dosage was directly compared at or near the critical levels required to achieve sterilization, shorter applications using higher dose rates had less effect on strength than longer applications using lower dose rates. Consequently, gamma radiation would have at least an indirect effect on the classification of biological durability when loss in bending strength or modulus of elasticity are considered (e.g. CEN/TS 15083-2 2005).

Sharman and Smith (1971) found that the lethal radiation dose depends on the wood moisture content (MC) and eventually also on the concentration of microorganisms in the wood. However, a radiation dose of $10-50 \mathrm{kGy}\left({ }^{60} \mathrm{Co}\right)$ was sufficient to kill all organisms in cubes $\left(19 \times 19 \times 19 \mathrm{~mm}^{3}\right)$ of ponderosa pine and birch (Betula sp.) sapwood. Furthermore, they found that there is no obvious aftereffect, resulting in an increased efficiency of killing of microorganisms with time, i.e. no hindered growth of microorganisms after unsterile conditioning afterwards. In a second study, Smith and Sharman (1971) examined the potential effects of gamma, wet-heat, and ethylene oxide treatments on subsequent decay of ponderosa pine and red alder sapwood. Solely after gamma radiation at $100 \mathrm{kGy}$, decay by Poria weirii increased slightly, but significantly.

Smith (1965) used methyl alcohol, propylene oxide and ethylene oxide to sterilize both Scots pine sapwood and European beech (Fagus sylvatica) wood blocks, where ethylene oxide was the most efficient sterilizing agent and methyl alcohol the least effective. However, toxic residues remaining in the wood blocks after sterilizing and ventilating 
treatment with propylene oxide seriously inhibited the subsequent growth of Lentinus lepideus. Ethylene oxide was also used by Smith and Sharman (1971) and was found to be highly efficient for sterilization.

Da Costa and Osborne (1970) observed toxic residual effects which may influence the results of decay tests when propylene oxide is used for sterilization and therefore recommended heat-sterilization. Grinda (1984) incubated untreated and preservative treated Scots pine sapwood specimens after sterilizing with three different methods: (1) sterilization in a steam pot at $100{ }^{\circ} \mathrm{C}$ for $10 \mathrm{~min}$ on two subsequent days, (2) ethylene oxide treatment in vacuum during 60 min at $55^{\circ} \mathrm{C}$ and subsequent laminar ventilation for 5 days, and (3) gamma radiation at $30 \mathrm{kGy}$. Results of subsequent decay tests with untreated wood were not significantly different between steam-treated and the ethylene oxide treated specimens. However, mass loss of preservative treated specimens was affected by previous ethylene oxide sterilization. Gamma treatment did not affect the decay test results with treated wood specimens.

Mass loss due to fungal decay is usually calculated based on the oven-dry mass of the test specimens before and after incubation with wood-destroying fungi (EN 113-1 2021; EN 113-2 2021). However, the oven-dry mass should not be determined by oven-drying of the test specimens. Instead, additional moisture control specimens are dried after they had been conditioned in normal climate, i.e. at $20{ }^{\circ} \mathrm{C} / 65 \%$ relative humidity $(\mathrm{RH})$, together with the test specimens. The theoretical oven-dry mass of the test specimens is calculated based on the equilibrium moisture content (EMC) of the moisture control specimens (see also Eq. 3) assuming that both, EMC of moisture control specimens and test specimens, are identic. The EMC of wood can vary significantly within a wood species (Hernández 2007; Alfredsen et al. 2021) and even within a single tree (Hill et al. 2015). Consequently, the use of moisture control specimens is attributed to systematic mistakes, whose amplitude depends on the wood species, the sampling procedure, and the variation of treatment intensity of modified or otherwise treated timbers (Zhou et al. 2013).

Oven-drying of test specimens might affect the results of durability tests since volatile organic compounds evaporate from the tested material at elevated temperatures. Such compounds are usually efficient against wood-destroying organisms, such as resins or terpenoids (Taylor et al. 2002), or may be easily accessible food sources subtracted from the substrate before the test begins, such as soluble carbohydrates. Both ways, the mass loss caused by fungal decay can be affected, especially when the test specimens undergo a leaching procedure prior to incubation.

The negative effect of oven-drying on the durability of different hardwood and softwood species against wooddestroying fungi was shown in different studies by Bavendamm $(1941,1943)$, where both the mass loss of the tested wood and of the tested reference wood can be affected. Scots pine sapwood, that served as reference and virulence control in different European standard tests (e.g. EN 113-1 2021; EN 113-2 2021; ENV 807 2001), contains pinosylvin, which has an inhibitory effect on fungal growth (Celimene et al. 1999) but evaporates at elevated temperatures.

This study aimed at examining the effects of different sterilization techniques and methods to determine the ovendry mass of wood specimens on their durability against obligatory standard test fungi. It was hypothesized that sterilization, for example by gamma irradiation, can lead to a physical pre-degradation of cell wall components and/or wood ingredients which may have a negative effect on the biological durability of wood. Similarly, high temperatures during oven-drying, steam and autoclave sterilization may negatively affect wood durability since volatile compounds may evaporate from the wood (Table 1). Since such potentially negative effects apply to both the wood material under
Table 1 Hypothesized effects of different treatments used for sterilization, pre-ageing, and determination of oven-dry weights of specimens in wood durability tests

\begin{tabular}{|c|c|c|}
\hline \multirow[t]{2}{*}{ Treatment } & \multicolumn{2}{|c|}{ Hypothesized effects on fungal decay of wood test specimens } \\
\hline & Positive & Negative \\
\hline Gamma sterilization & $\begin{array}{l}\text { Formation of free radicals leading to cleavage } \\
\text { of hydrogen bonds, increased accessibility of } \\
\text { cellulose and hemicellulose molecules }\end{array}$ & - \\
\hline $\begin{array}{l}\text { Fumigants (e.g. bro- } \\
\text { mine methane) }\end{array}$ & - & Toxic residual effects \\
\hline $\begin{array}{l}\text { Autoclaving } \\
\text { Steam treatment } \\
\text { Oven-drying }\end{array}$ & $\begin{array}{l}\text { Loss of volatile inhibiting substances, e.g. } \\
\text { resins, and cleavage of bonds, e.g. } \alpha \text { - and } \\
\beta \text {-alkyl-aryl ether bonds in lignin, leading to } \\
\text { higher accessibility }\end{array}$ & - \\
\hline Alcohol & - & - \\
\hline Leaching & Loss of inhibitory substances & Loss of easily accessible substances \\
\hline None & - & $\begin{array}{l}\text { Contamination with non-target } \\
\text { organisms, antagonistic effects }\end{array}$ \\
\hline
\end{tabular}


test and the respective non-durable reference wood species, consequences on durability classification should also be analysed.

\section{Materials and methods}

\subsection{Wood specimens}

Specimens of $15 \times 25 \times 50$ (ax.) $\mathrm{mm}^{3}$ were prepared from Scots pine sapwood and heartwood (Pinus sylvestris L.), European beech (Fagus sylvatica L.), and English oak heartwood (Quercus robur L.) according to CEN/TS 15083-1 (2005) and EN 113-2 (2021). All specimens were free from defects such as cracks, knots, resin pockets, discoloration and decay. They were cut from single stems to reduce the effect of intra-species variation in material resistance. Trees were harvested in Lower Saxony nearby the city of Goettingen, and cut into boards, which were air-dried before specimen preparation. In total, 1120 decay test specimens were made, evenly assigned to different methods of sterilization and oven-dry mass determination, and $n=10$ replicate specimens were used for each combination. All specimens were pre-aged according to EN 84 (2020), and therefore submerged in deionized water in plastic containers. After a vacuum impregnation at $4 \mathrm{kPa}$ during $20 \mathrm{~min}$, the specimens were kept submerged and the water was exchanged ten times during 14 days. After the leaching procedure, the specimens were carefully dried.

\subsection{Determination of oven-dry mass}

The oven-dry mass of the specimens was determined using either the oven-drying method (ODM) or the moisture equilibrium method (MEM). Half of the specimens was assigned to each of the methods. Firstly, all specimens were conditioned at $20^{\circ} \mathrm{C} / 65 \% \mathrm{RH}$ until constant mass was achieved. Half of the specimens assigned to the different sterilization methods was oven-dried at $103 \pm 2{ }^{\circ} \mathrm{C}$ for $48 \mathrm{~h}$ and weighed to the nearest $0.001 \mathrm{~g}$. The wood moisture content (MC) of the oven-dried wood specimens was calculated according to Eq. 1 . The theoretical oven-dry mass $\left(\mathrm{m}_{0, \mathrm{th}}\right)$ of the second half of the specimens, which had not been dried, was calculated using the mean wood MC of the corresponding specimen sets from the first half according to Eq. 2.

Equation 1: Calculation of wood moisture content MC:

$M C=\frac{m_{c}-m_{0, L}}{m_{0, L}} \cdot 100 \quad[\%]$ $\mathrm{m}_{\mathrm{c}}=$ mass after conditioning at $20{ }^{\circ} \mathrm{C} / 65 \% \mathrm{RH}[\mathrm{g}]$. $\mathrm{m}_{0, \mathrm{~L}}=$ oven-dry mass after leaching $[\mathrm{g}]$.

Equation 2: Calculation of theoretical oven-dry mass $\mathrm{m}_{0, \mathrm{th}}$ :

$m_{0, t h}=\frac{m_{c} \cdot 100}{100+M C} \quad[\mathrm{~g}]$

$\mathrm{m}_{0, \text { th }}=$ theoretical oven-dry mass $[\mathrm{g}] . \mathrm{m}_{\mathrm{c}}=$ mass after conditioning at $20{ }^{\circ} \mathrm{C} / 65 \% \mathrm{RH}[\mathrm{g}]$. $\mathrm{MC}=$ mean wood moisture content [\%].

\subsection{Wood sterilization}

Five different methods of wood sterilization were applied to the specimens before the fungal incubation experiments. In addition, non-sterilized specimens were tested. Wood specimens were submitted to gamma irradiation at two different dosages, i.e. $25 \mathrm{kGy}$ and $50 \mathrm{kGy}$. Therefore, the specimens were vacuum-packed in polyethylene bags and shipped to BBF Sterilisationsservice GmbH (Kernen-Rommelshausen, Germany), where the radiation was applied in one or two radiation treatments, respectively. Steam sterilization was conducted according to CEN/TS 15083-1 (2005) in a steam pot at $100{ }^{\circ} \mathrm{C}$ for $20 \mathrm{~min}$, and repeated after $24 \mathrm{~h}$ again at $100{ }^{\circ} \mathrm{C}$ for $10 \mathrm{~min}$. Specimens were autoclaved at the target temperature of $121{ }^{\circ} \mathrm{C}$ for $20 \mathrm{~min}$ in a vertical autoclave 5075 ELVC Tuttnauer Systec, Linden, Germany). The total duration of the autoclavation treatments was 150 min including heating and cooling. During steam sterilization and autoclave treatment the specimens were wrapped in aluminum foil.

Further sets of specimens were sterilized through ovendrying at $103 \pm 2{ }^{\circ} \mathrm{C}$ for $48 \mathrm{~h}$ and through dipping in pure ethanol for approx. $4 \mathrm{~s}$. Ethanol-sterilized specimens were allowed to evaporate for $10 \mathrm{~min}$ before they were incubated.

\subsection{Durability tests with monocultures of Coniophora puteana and Trametes versicolor}

Laboratory decay resistance tests were conducted according to a modified CEN/TS 15083-1 (2005) protocol as follows: two specimens of the same species and pre-treatment (sterilization, oven-drying or conditioning) were placed on fungal mycelium in a Kolle flask. To avoid direct contact between wood and overgrown malt agar (4\%) stainless steel washers were placed in between. The incubation time was 16 weeks. The following test fungi were used: Coniophora puteana $=($ Schum.:Fr.) P. Karsten BAM Ebw. 15 and Trametes versicolor $=(\mathrm{L} .:$ Fr. $)$ Pilat CTB 863A. Each wood species was incubated with both test fungi, except beech which served as reference solely against the white rot fungus $T$. 
versicolor. After incubation, the specimens were cleaned from adhering mycelium, weighed to the nearest $0.001 \mathrm{~g}$, and mass loss $\left(\mathrm{ML}_{\mathrm{F}}\right)$ calculated according to Eq. 3.

Equation 3: Calculation of mass loss by fungal decay $\mathrm{ML}_{\mathrm{F}}$ :

$M L_{F}=\frac{m_{0, L}-m_{0, F}}{m_{0, L}} \cdot 100 \quad[\%]$

$\mathrm{m}_{0, \mathrm{~L}}=$ oven-dry mass before incubation after leaching. $\mathrm{m}_{0, \mathrm{~F}}=$ oven-dry mass after incubation.

\subsection{Durability classification and statistical analysis}

The durability of Scots pine and English oak heartwood was classified according to EN 350 (2016) based on median $\mathrm{ML}_{\mathrm{F}}$ according to CEN/TS 15083-1 (2005). Furthermore, x-values (Table 2) were calculated for the different combinations of sterilization pre-treatment and methods of determination of the oven-dry mass. The x-values were calculated based on both, the median (according to CEN/TS 15083-1 2005) and the mean mass loss $\mathrm{ML}_{\mathrm{F}}$ and used for durability classification according to CEN/TS 15083-2 (2005) and EN 350 (2016).

The arithmetic mean and the median were calculated for mass loss data $\left(\mathrm{ML}_{\mathrm{F}}\right)$. The standard deviation (SD) was used to calculate the coefficients of variation (COV) as a percentage of the corresponding mean value. Significance of differences between mean values of two collectives was tested with the help of a parametric two-sample t-test. Normal distribution of the sample was assumed when the number of replicates was $n \geq 30$. For $n<30$, a ShapiroWilks test was used to test for normal distribution. When the sample was not normal-distributed the non-parametric Mann-Whitney-U-test was applied. Depending on the probability of error, four levels of significance were distinguished as follows: $\alpha<0.1(-), 0.1 \leq \alpha<1(+), 1 \leq \alpha<5(++)$, and $\alpha \geq 5(+++)$.

\section{Results and discussion}

\subsection{Mass loss by fungal decay $\left(\mathrm{ML}_{\mathrm{F}}\right)$}

The mass loss $\left(\mathrm{ML}_{\mathrm{F}}\right)$ after 16 weeks of incubation following one of the six sterilization treatments did not differ significantly, neither in brown nor white rot tests (Table 3 and Fig. 1), which is contradicting previous results by Hasan et al. (2008) who found higher $\mathrm{ML}_{\mathrm{F}}$ on gamma-sterilized compared to autoclaved specimens. Grinda (1984) also observed no negative effect of gamma radiation on fungal resistance of wood compared to steam-sterilized wood blocks, but applied a radiation dosage of $30 \mathrm{kGy}$, which was the lowest of the different dosages applied by Hasan et al. (2008). However, in this study neither the lower dosage at $25 \mathrm{kGy}$ nor the higher one at $50 \mathrm{kGy}$ had a significant effect on $\mathrm{ML}_{\mathrm{F}}$.

Oven-drying for determining the absolute dry weight of Scots pine sapwood and heartwood specimens led to higher $\mathrm{ML}_{\mathrm{F}}$ compared to specimens which had been conditioned in normal climate. Hence, previous findings by Bavendamm (1941, 1943) were confirmed and recommendation in respective test standards (e.g EN 113-1 2021; EN 113-2 2021) were supported. The higher $M_{F}$ might be attributed to the loss of volatile compounds such as resin, resin acids, or pinosylvin, which all positively affect the biological durability of Scots pine wood, both sapwood and heartwood (Harju et al. 2003). However, with respect to practical applications one might question how meaningful it is to determine the biological durability of Scots pine which never experienced temperatures above $60{ }^{\circ} \mathrm{C}$, since the majority of sawn conifer timber is kiln-dried at temperatures far beyond $60{ }^{\circ} \mathrm{C}$ (Oltean et al. 2007).

The $\mathrm{ML}_{\mathrm{F}}$ of non-sterilized English oak and beech specimens was significantly lower compared to sterilized specimens independent of the applied sterilization method when specimens were not oven-dried. Obviously, contamination with mold led to antagonistic effects and inhibited the growth and decay activity of $T$. versicolor.
Table 2 Durability classes (DC) of wood to fungal attack (basidiomycete fungi) based on median mass loss (according to CEN/TS 15083-1 2005) and $\mathrm{x}$-values (according to EN 350 2016 and CEN/TS 15083-2 2005)

\begin{tabular}{llll}
\hline Durability class & Description & Percentage mass loss (ML) & $\mathrm{x}^{1}$-value $^{2}$ \\
\hline DC 1 & Very durable & $\mathrm{ML} \leq 5 \%$ & $\mathrm{x} \leq 0.10$ \\
DC 2 & Durable & $5 \%<\mathrm{ML} \leq 10 \%$ & $0.10<\mathrm{x} \leq 0.20$ \\
DC 3 & Moderately durable & $10 \%<\mathrm{ML} \leq 15 \%$ & $0.20<\mathrm{x} \leq 0.45$ \\
DC 4 & Less durable & $15 \%<\mathrm{ML} \leq 30 \%$ & $0.45<\mathrm{x} \leq 0.80$ \\
DC 5 & Non durable & $\mathrm{ML}>30 \%$ & $\mathrm{x}>0.80$ \\
\hline
\end{tabular}

${ }^{1} \mathrm{ML}=$ highest of the median mass losses (in \%) determined for test specimens exposed to each of the used test fungi in decay tests according to CEN/TS 15083-1 (2005)

${ }^{2}$ Hardwoods: $\mathrm{x}=$ median value of mass loss for timber test specimens/median value of mass loss for beech reference test specimens; Softwoods: $\mathrm{x}=$ median value of mass loss for timber test specimens/median value of mass loss for Scots pine sapwood reference test specimens 
Table 3 Median mass loss due to fungal attack $\left(\mathrm{ML}_{\mathrm{F}}\right)$ of Scots pine sapwood and heartwood, English oak, and beech specimens after 16 weeks of incubation with $C$. puteana and $T$. versicolor and different sterilization treatments and procedures of determining the ovendry mass $(\mathrm{ODM}=$ oven-dry method, $\mathrm{MEM}=$ moisture equilibrium method)

\begin{tabular}{|c|c|c|c|c|}
\hline & \multicolumn{2}{|c|}{ Coniophora puteana } & \multicolumn{2}{|c|}{$\begin{array}{l}\text { Trametes versi- } \\
\text { color }\end{array}$} \\
\hline & ODM & MEM & ODM & MEM \\
\hline \multicolumn{5}{|c|}{ Scots pine heartwood } \\
\hline Gamma 25 kG & 14.2 & 0.4 & 8.0 & 6.8 \\
\hline Gamma 50 kG & 19.2 & 3.1 & 6.8 & 5.2 \\
\hline Steam & 16.8 & 1.3 & 6.6 & 5.8 \\
\hline Autoclave & 14.4 & 4.5 & 5.8 & 5.4 \\
\hline Drying & 14.8 & 6.4 & 9.0 & 8.3 \\
\hline Ethanol & 14.4 & 2.6 & 8.8 & 6.5 \\
\hline Unsterile & 8.5 & 2.1 & 8.0 & 2.5 \\
\hline \multicolumn{5}{|c|}{ Scots pine sapwood } \\
\hline Gamma 25 kG & 31.2 & 23.5 & 21.7 & 19.4 \\
\hline Gamma 50 kG & 35.2 & 21.7 & 21.4 & 22.1 \\
\hline Steam & 31.3 & 22.3 & 21.2 & 21.8 \\
\hline Autoclave & 31.3 & 27.4 & 18.5 & 18.6 \\
\hline Drying & 31.4 & 17.5 & 20.5 & 19.4 \\
\hline Ethanol & 27.3 & 0.2 & 25.0 & 26.5 \\
\hline Unsterile & 30.8 & 23.4 & 20.0 & 21.9 \\
\hline \multicolumn{5}{|l|}{ English oak } \\
\hline Gamma 25 kG & 1.1 & -0.8 & 22.6 & 23.1 \\
\hline Gamma 50 kG & 0.4 & -0.2 & 23.0 & 22.0 \\
\hline Steam & 0.7 & 0.5 & 23.2 & 24.1 \\
\hline Autoclave & 0.8 & 0.7 & 22.9 & 23.5 \\
\hline Drying & 0.4 & 0.5 & 22.6 & 24.9 \\
\hline Ethanol & -0.5 & 0.1 & 24.1 & 20.7 \\
\hline Unsterile & -0.6 & 0.7 & 25.5 & 1.4 \\
\hline \multicolumn{5}{|l|}{ Beech } \\
\hline Gamma 25 kG & 33.7 & 34.9 & 26.1 & 27.3 \\
\hline Gamma 50 kG & 35.3 & 35.9 & 28.6 & 27.0 \\
\hline Steam & 32.9 & 32.9 & 26.4 & 26.7 \\
\hline Autoclave & 29.1 & 23.8 & 26.2 & 26.0 \\
\hline Drying & 33.3 & 30.4 & 29.5 & 28.5 \\
\hline Ethanol & 25.6 & 29.2 & 25.8 & 29.0 \\
\hline Unsterile & 33.4 & 30.7 & 26.7 & 7.7 \\
\hline
\end{tabular}

Generally, the variation in $\mathrm{ML}_{\mathrm{F}}$ differed between combinations of test fungus, wood species, and method of sterilization and oven-dry weight determination, but did not show any clear tendency.

\subsection{Durability classes}

The mass loss data obtained in the agar plate tests according to EN 113-2 (2021) were used to assign durability classes to the wood species in dependence of the sterilization treatment and method of determining the oven-dry mass (Table 4). The reference species beech was assigned to DC 5 in each case except when tested in unsterile state after conditioning against $T$. versicolor, where most likely the test fungus was inhibited through mold growth. The second reference species Scots pine sapwood was assigned to DC 5 against C. puteana except after an ethanol treatment. As expected, Scots pine sapwood revealed slightly higher durability against $T$. versicolor (i.e. DC 4), because softwoods generally show less susceptibility to white rot fungi.

English oak was very durable against $C$. puteana (i.e. DC 1 ), but only less durable (DC 4) against $T$. versicolor when the median $\mathrm{ML}_{\mathrm{F}}$ was considered, and only non-durable (DC 5 ) in most cases when $\mathrm{x}$-values were considered. The use of either median or mean $\mathrm{ML}_{\mathrm{F}}$ for calculating $\mathrm{X}$-values did not lead to clear differences in durability classification.

The durability classification of Scots pine heartwood was most sensitive to the impact of the different methods of sterilization and determination of the oven-dry mass. Generally, the use of $x$-values led to lower durability since the reference Scots pine sapwood had been more durable than DC 5 as per definition according to EN 350 (2016), i.e. less durable (DC 4), and non-durable (DC 5) only after oven-drying. Consequently, the wood species under test achieved higher durability when compared with the reference.

The oven-drying method for determining the absolute dry mass of the specimens reduced the durability of Scots pine heartwood remarkably, in extreme cases up to 3 DCs when those are assigned on the basis of $\mathrm{ML}_{\mathrm{F}}$ by $C$. puteana. Again, the loss of volatile compounds during drying such as resin, resin acids, and stilbenes (e.g. pinosylvin) may explain its reduced durability.

Furthermore, the different sterilization methods affected the durability of Scots pine heartwood especially against $C$. puteana: Using the median $\mathrm{ML}_{\mathrm{F}}$ resulted in DC 1-2 (MEM) and DC 3-4 (ODM), respectively. In contrast, DC 4 was achieved independent from the sterilization method when $\mathrm{x}$-values were used and the ODM was applied. The highest variation in durability classification (DC 1-5) resulted from $\mathrm{x}$-values after applying the MEM.

The use of the mean instead of the median $\mathrm{ML}_{\mathrm{F}}$ for calculating X-values led to lower durability of Scots pine heartwood when it was not oven-dried before. In most cases the material was assigned to the next worse class. Solely, after ethanol sterilization the durability increased from DC 5 to DC 4. 

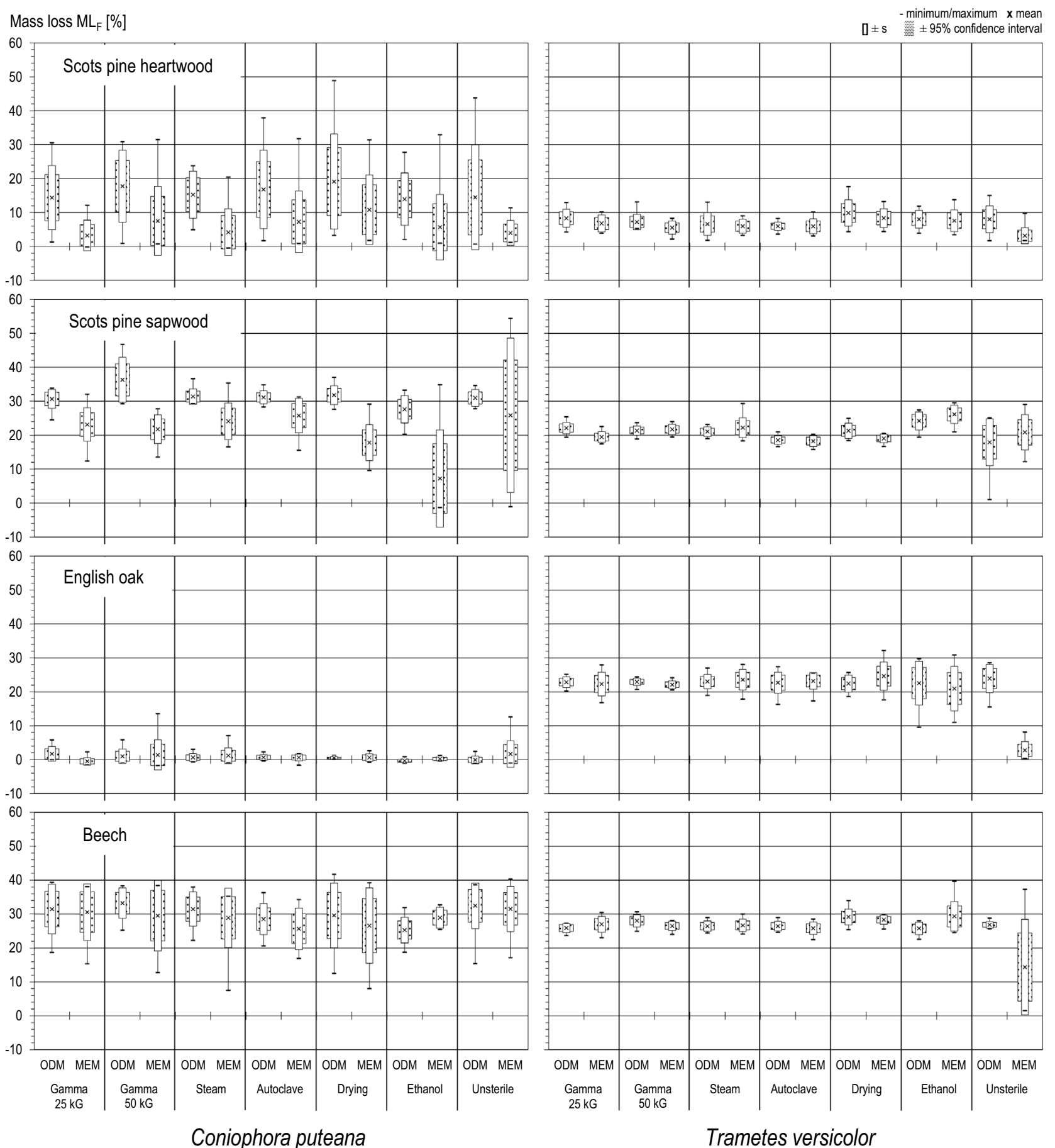

Fig. 1 Percentage mass loss $\left(\mathrm{ML}_{\mathrm{F}}\right)$ of Scots pine sapwood and heartwood, English oak, and beech specimens after 16 weeks of incubation with $C$. puteana and $T$. versicolor and different steriliza-

tion treatments and procedures of determining the oven-dry mass $(\mathrm{ODM}=$ oven-dry method, $\mathrm{MEM}=$ moisture equilibrium method $)$

\section{Conclusion}

- Sterilization of wood specimens is needed since contamination with mould and other 'non-target' organisms can lead to inhibition of the test fungus. This does not necessarily happen, but cannot be obviated.

this study: 
Table 4 Durability classes (DC) of wood to fungal attack (basidiomycete fungi) based on median mass loss $\mathrm{ML}_{\mathrm{F}}$ (according to CEN/TS 15083-1 2005) and $\mathrm{x}$-values (according to EN 350 2016) based on the median $\mathrm{ML}_{\mathrm{F}}$, and the mean $\mathrm{ML}_{\mathrm{F}}$ in brackets $(\mathrm{ODM}=$ ovendry method, $\mathrm{MEM}=$ moisture equilibrium method)

\begin{tabular}{|c|c|c|c|c|c|c|c|c|}
\hline & \multicolumn{4}{|c|}{ Coniophora puteana } & \multicolumn{4}{|c|}{ Trametes versicolor } \\
\hline & \multicolumn{2}{|c|}{$\underline{\text { Median } \mathrm{ML}_{\mathrm{F}}}$} & \multicolumn{2}{|c|}{$x$-value } & \multicolumn{2}{|c|}{$\underline{\text { Median } \mathrm{ML}_{\mathrm{F}}}$} & \multicolumn{2}{|l|}{$x$-value } \\
\hline & ODM & MEM & ODM & MEM & ODM & MEM & ODM & MEM \\
\hline \multicolumn{9}{|c|}{ Scots pine heartwood } \\
\hline Gamma 25 kG & 3 & 1 & $4(4)$ & $1(2)$ & 2 & 2 & $3(3)$ & $3(3)$ \\
\hline Gamma $50 \mathrm{kG}$ & 4 & 1 & $4(4)$ & $2(3)$ & 2 & 2 & $3(3)$ & $3(3)$ \\
\hline Steam & 4 & 1 & $4(4)$ & $1(2)$ & 2 & 2 & $3(3)$ & $3(3)$ \\
\hline Autoclave & 3 & 1 & $4(4)$ & $2(3)$ & 2 & 2 & $3(3)$ & $3(3)$ \\
\hline Drying & 3 & 2 & $4(4)$ & $3(4)$ & 2 & 2 & $3(4)$ & $3(3)$ \\
\hline Ethanol & 3 & 1 & $4(4)$ & $5(4)$ & 2 & 2 & $3(3)$ & $3(3)$ \\
\hline Unsterile & 2 & 1 & $3(4)$ & $1(2)$ & 2 & 2 & $3(4)$ & $3(2)$ \\
\hline \multicolumn{9}{|c|}{ Scots pine sapwood } \\
\hline Gamma 25 kG & 5 & 4 & - & - & 4 & 4 & - & - \\
\hline Gamma $50 \mathrm{kG}$ & 5 & 4 & - & - & 4 & 4 & - & - \\
\hline Steam & 5 & 4 & - & - & 4 & 4 & - & - \\
\hline Autoclave & 5 & 4 & - & - & 4 & 4 & - & - \\
\hline Drying & 5 & 4 & - & - & 4 & 4 & - & - \\
\hline Ethanol & 4 & 1 & - & - & 4 & 4 & - & - \\
\hline Unsterile & 5 & 4 & - & - & 4 & 4 & - & - \\
\hline \multicolumn{9}{|l|}{ English oak } \\
\hline Gamma $25 \mathrm{kG}$ & 1 & 1 & $1(1)$ & $1(1)$ & 4 & 4 & $5(5)$ & $5(5)$ \\
\hline Gamma $50 \mathrm{kG}$ & 1 & 1 & $1(1)$ & $1(1)$ & 4 & 4 & $5(5)$ & $5(5)$ \\
\hline Steam & 1 & 1 & $1(1)$ & $1(1)$ & 4 & 4 & $5(5)$ & $5(5)$ \\
\hline Autoclave & 1 & 1 & $1(1)$ & $1(1)$ & 4 & 4 & $5(5)$ & $5(5)$ \\
\hline Drying & 1 & 1 & $1(1)$ & $1(1)$ & 4 & 4 & $4(4)$ & $5(5)$ \\
\hline Ethanol & 1 & 1 & $1(1)$ & $1(1)$ & 4 & 4 & $5(5)$ & $4(4)$ \\
\hline Unsterile & 1 & 1 & $1(1)$ & $1(1)$ & 4 & 1 & $5(5)$ & $2(2)$ \\
\hline \multicolumn{9}{|l|}{ Beech } \\
\hline Gamma $25 \mathrm{kG}$ & 5 & 5 & - & - & 5 & 5 & - & - \\
\hline Gamma $50 \mathrm{kG}$ & 5 & 5 & - & - & 5 & 5 & - & - \\
\hline Steam & 5 & 5 & - & - & 5 & 5 & - & - \\
\hline Autoclave & 5 & 5 & - & - & 5 & 5 & - & - \\
\hline Drying & 5 & 5 & - & - & 5 & 5 & - & - \\
\hline Ethanol & 5 & 5 & - & - & 5 & 5 & - & - \\
\hline Unsterile & 5 & 5 & - & - & 5 & 2 & - & - \\
\hline
\end{tabular}

- Strictly following the standards (EN 113-2 2021), i.e. applying the MEM and steam or gamma sterilization at $25 \mathrm{kGy}$, led to DC 1 for Scots pine heartwood, which contradicts the current classification of DC 3-4 according to EN 350 (2016). The overwhelming majority of pine timber used in the building sector is kiln-dried at temperatures often above $60{ }^{\circ} \mathrm{C}$ and therefore experienced a loss of volatile compounds. Furthermore, longterm natural weathering comes along with a loss of volatile compounds by evaporation. Consequently, avoidance of high temperatures prior to durability tests does not well reflect the anticipated use conditions.
- The combination of using the ODM and $\mathrm{x}$-values for assigning DCs turned out to be least affected by the sterilization method. Furthermore, the durability classification becomes independent from the current virulence of the test fungus and higher reproducibility can be expected.

Acknowledgements Parts of this research were funded from the ongoing research project DURATEST (2219NR372), supported by the German Ministry of Food and Agriculture (BMEL) via the Agency of Renewable Resources (FNR).

Funding Open Access funding enabled and organized by Projekt DEAL. 


\section{Declarations}

Conflict of interest On behalf of all authors, the corresponding author states that there is no conflict of interest.

Open Access This article is licensed under a Creative Commons Attribution 4.0 International License, which permits use, sharing, adaptation, distribution and reproduction in any medium or format, as long as you give appropriate credit to the original author(s) and the source, provide a link to the Creative Commons licence, and indicate if changes were made. The images or other third party material in this article are included in the article's Creative Commons licence, unless indicated otherwise in a credit line to the material. If material is not included in the article's Creative Commons licence and your intended use is not permitted by statutory regulation or exceeds the permitted use, you will need to obtain permission directly from the copyright holder. To view a copy of this licence, visit http://creativecommons.org/licenses/by/4.0/.

\section{References}

Alfredsen G, Brischke C, Zimmer K, Marais BN, Stein RFA, Humar M (2021) Modelling the material resistance of wood-Part 1: utilizing durability test data based on different reference wood species. Forests 12(5):558

APHIS (2004) Rules and regulations_-importation of wood packaging material. In: Convention, animal and plant protection convention. 7 CFR, Part 319. Federal Register, vol 69, pp 55,719-55,733

Armstrong JW, Brash DW, Waddell BC (2014) Comprehensive literature review of fumigants and disinfestation strategies, methods and techniques pertinent to potential use as quarantine treatments for New Zealand export logs. Plant Food Res SPTS (10678)

ASTM D1413 - 05b (2005) Standard Test Method for Wood Preservatives by Laboratory Soil-Block Cultures. ASTM International, West Conshohocken

AWPA E10 (2015) Standard method of testing wood preservatives by laboratory soil-block cultures. American Wood Protection Association, Birmingham

Bavendamm W (1941) Weitere mykologische Dauerhaftigkeitsuntersuchungen mit luftgetrockneten und gedarrten Probeklötzchen. (Further mycological durability tests with air-dried and kiln-dried small test blocks). Holz Roh- Werkst 4:201-205 (In German)

Bavendamm W (1943) Über den Einfluß des Darrens von Holz auf seine Pilzanfälligkeit. (On the influence of kiln-drying wood on its susceptibility to fungi). Holz Roh- Werkst 6:161-166 (In German)

Celimene CC, Micales JA, Ferge L, Young RA (1999) Efficacy of pinosylvins against white-rot and brown-rot fungi. Holzforschung 53:491-497

CEN/TS 15083-1 (2005) Durability of wood and wood-based products-Determination of the natural durability of solid wood against wood-destroying fungi, test methods-Part 1: Basidiomycetes. European Committee for Standardization, Brussels

CEN/TS 15083-2 (2005) Durability of wood and wood-based products-Determination of the natural durability of solid wood against wood-destroying fungi, test methods-Part 2: Soft rotting micro-fungi. European Committee for Standardization, Brussels

Chapman AD (1933) Effect of steam sterilization on susceptibility of wood to blue-staining and wood-destroying fungi. J Agric Res 47:369-374

Curling S, Winandy JE (2008) Comparison of the effects of gamma irradiation and steam sterilization on southern pine sapwood. For Prod J 58:87-90
Da Costa E, Osborne LD (1970) Residual fungitoxic effects of propylene oxide sterilization of creosoted wood. Trans Br Mycol Soc $55: 337-340$

EN 84 (2020) Durability of wood and wood-based products-Accelerated ageing of treated wood prior to biological testing-Leaching procedure. European Committee for Standardization, Brussels

EN 113-1 (2021) Durability of wood and wood-based products-Test method against wood destroying basidiomycetes-Part 1: Assessment of biocidal efficacy of wood preservatives. European Committee for Standardization, Brussels

EN 113-2 (2021) Durability of wood and wood-based products-Test method against wood destroying basidiomycetes-Part 2: Assessment of inherent or enhanced durability. European Committee for Standardization, Brussels

EN 350 (2016) Durability of wood and wood-based products-Testing and classification of the durability to biological agents of wood and wood-based materials. European Committee for Standardization, Brussels

ENV 807 (2001) Wood preservatives-Determination of the effectiveness against soft rotting micro-fungi and other soil inhabiting micro-organisms. European Committee for Standardization, Brussels

Freitag CM, Morrell JJ (1998) Use of gamma radiation to eliminate fungi from wood. For Prod J 48:76-78

Grinda M (1984) Einfluß des Sterilisationsverfahrens bei Holzschutzmittelprüfungen mit Pilzen. (Influence of the sterilization process on wood preservatives tests with fungi). Holz Roh- Werkst 42:194 (In German)

Hansen J (1972) Sterilization of test objects for mycological testing using electron radiation. Material Und Organismen 7:73-80

Harju AM, Venäläinen M, Anttonen S, Viitanen H, Kainulainen P, Saranpää P, Vapaavuori E (2003) Chemical factors affecting the brown-rot decay resistance of Scots pine heartwood. Trees 17:263-268

Hasan M, Despot R, Sinković T, Jambreković V, Bogner A, Humar M (2008) The influence of sterilisation by gamma radiation on natural durability of wood. Wood Res 53:23-34

Hernández RE (2007) Moisture sorption properties of hardwoods as affected by their extraneous substances, wood density, and interlocked grain. Wood Fiber Sci 39:132-145

Hill CA, Ramsay J, Gardiner B (2015) Variability in water vapour sorption isotherm in Japanese Larch (Larix kaempferi Lamb.)earlywood and latewood influences. Int Wood Prod J 6:53-59

IPPC (2002) Guidelines for regulating wood packaging material in international trade. ISPM Pub. No. 15. FAO, Rome: International Plant Protection Convention

Kacik F, Luptáková J, Šmíra P, Nasswettrová A, Kačíková D, Vacek V (2016) Chemical alterations of pine wood lignin during heat sterilization. BioResources 11:3442-3452

Katsumata N, Yoshimura T, Tsunoda K, Imamura Y (2007) Resistance of gamma-irradiated sapwood of Cryptomeria japonica to biological attacks. J Wood Sci 53:320-323

Oltean L, Teischinger A, Hansmann C (2007) Influence of temperature on cracking and mechanical properties of wood during wood drying-a review. BioResources 2:789-811

Scheffer TC (1963) Effect of gamma radiation on decay resistance of wood. For Prod J 13:208

Schmidt EL, French DW (1979) Sterilization method effects on germination of wood decay fungus spores observed by the contact agar method. Nature 227:300-301

Sharman CV, Smith RS (1971) Gamma radiation sterilization of ponderosa pine and birch sapwood. Wood Fiber Sci 2:134-143

Smith RS (1965) Sterilization of wood test blocks by volatile chemicals: Effects on Lentinus lepideus. Trans Br Mycol Soc 48:341-347 
Smith RS, Sharman CV (1971) Effect of gamma radiation, wet-heat, and ethylene oxide sterilization of wood on its subsequent decay by four wood-destroying fungi. Wood Fiber Sci 2:356-362

Taylor AM, Gartner BL, Morrell JJ (2002) Heartwood formation and natural durability—a review. Wood Fiber Sci 34:587-611

Wang X (2010) Heat sterilization of wood. Wood handbook: wood as an engineering material: chapter 20. Centennial ed. General technical report FPL; GTR-190. Madison, WI: US Dept. of Agriculture, Forest Service, Forest Products Laboratory, p 20.1-20.13
Zhou Q, Tu D, Liao L, Guo Q (2013) Variation of equilibrium moisture content of heat-treated Couratari oblongifolia, Fraxinus excelsior, and Quercus rubra wood. BioResources 8:182-188

Publisher's Note Springer Nature remains neutral with regard to jurisdictional claims in published maps and institutional affiliations. 